\title{
Pilot study assessing distressors affecting patients with cancer using the distress thermometer screening tool
}

\author{
Rana Yamout ${ }^{1}$, Jeanny Aragon-Ching ${ }^{2}$, Mary Abed Al Ahad ${ }^{3}$, Ali Taher ${ }^{4}$ and Antoine Finianos ${ }^{4 *}$ \\ ${ }^{1}$ Department of Anesthesiology, American University of Beirut Medical Center, Beirut, Lebanon \\ ${ }^{2}$ GU Medical Oncology, Inova Schar Cancer Institute, Fairfax, VA, USA \\ ${ }^{3}$ Clinical Research Institute, American University of Beirut, Beirut, Lebanon \\ ${ }^{4}$ Department of Internal Medicine, American University of Beirut Medical Center, Beirut, Lebanon
}

\begin{abstract}
Background: Distress is an inevitable and debilitating emotion experienced by those with cancer that has been shown to impact quality of life (QOL) and overall survival. It can manifest from emotional, physical, spiritual, or psychiatric stressors. We sought to determine the prevalence of distress during initiation of chemotherapy for cancer in the George Washington Medical Center, Washington D.C.

Methods: The distress screening thermometer results were retrospectively evaluated from a single institution from patients who attended outpatient office clinic visits in an urban institution from 2014 - 2015 using the Distress Thermometer/Problem list (DT/PL) version 3.2012. Pearson's correlation coefficient was used to examine correlation between the scores of each problem area. Multivariate linear regression models were used to examine the association between the overall distress thermometer score and each of the five problem areas. One-way Anova tests were conducted to examine whether the mean distress score and the mean of each problem varied significantly between the cancer types.

Results: Females comprised $61.2 \%$ of the study sample and the mean age of the sample was 60 . The mean distress score was 3.6 (SD= 3.0 ). The strongest correlation between the various problem areas was found between emotional and practical problems (correlation coefficient $=0.38$ followed by a correlation of 0.30 between practical and family problems. The highest mean distress score (4.91) was observed in lung cancer patients while the lowest (2.56) was found in genitourinary cancer patients; however, the difference in the mean of distress scores between the cancer types was not significant $(\mathrm{p}=0.107)$.

Conclusions: Distress is common among patients starting chemotherapy. Distress scores differ among various cancer types and also among various population of patients making it difficult to extrapolate data about distress from one population to another. Every institution is encouraged to study distress in its cancer population in order to understand the various parameters contributing to such distress thus helping these institutions implement a multidisciplinary distress screening program that help identify those patients in need of further evaluation and management.
\end{abstract}

\section{Introduction}

Distress is a non-stigmatic description of emotional, physical, spiritual or psychiatric stressors experienced by patients diagnosed with cancer [1]. Per the National Comprehensive Cancer Network (NCCN) panel, "distress extends along a continuum, ranging from common normal feelings of vulnerability, sadness, and fears to problems that can become disabling, such as depression, anxiety, panic, social isolation, and existential and spiritual crisis". The NCCN issued a consensus statement recognizing distress screening as a standard of care in oncology. This was endorsed by the American Psychosocial Oncology Society in 2000 [2]. This was further enhanced by the Institute of Medicine (IOM) in their report in 2008: Cancer Care for the Whole Patient: Meeting Psychosocial Health Needs, in which the report discussed guidelines for detection and management of distress in cancer patients by incorporating psychosocial services as standard of care in these patients [3]. In 2015, the American College of Surgeons'.

With advancements of cancer treatment comes improved survival but also treatment-related side effects that can contribute to various distress symptoms [5-7]. Distress is also a risk factor for non-compliance with treatment [8]. For example, in a meta-analysis, depressed patients were three times more likely to be non-compliant compared to non-depressed patients [9]. Although cancer patients with pre-existing psychiatric disorders are at increased risk of moderate to severe distress, patients, especially those starting chemotherapy, will experience some form of distress that can affect their quality of life, compliance, and even survival [9-12]. Distress is common in cancer patients with various reports reporting different rates as these rates are affected by patient demographics, types of cancer and respective treatments $[13,14]$. For example, in a German study involving 3724 cancer patients, high levels of distress (distress thermometer DT $\geq 5$ ) was found in $52 \%$ of patients [15]. However, Zabora and colleagues, albeit using a different scale though, have found high distress in around $35 \%$ of patients in their study [16].

${ }^{*}$ Correspondence to: Antoine Finianos MD, Department of Internal Medicine, Division of Hematology and Oncology, Naef K. Basile Cancer Institute, The American University of Beirut Cancer Center, Lebanon, E-mail: af72@aub.edu.lb

Key words: distress, cancer, NCCN Distress thermometer/Problem list, psychosocial Received: April 23, 2020; Accepted: June 19, 2020; Published: June 22, 2020 
Despite distress being common in the cancer population of patients, less than a third of cancer patients with distress are recognized and subsequently referred for further evaluation and intervention [17]. When compared to using standardized tools like the distress thermometer (DT) for assessment of distress in cancer patients, clinical judgement by physicians and nurses failed to identify distress appropriately $[18,19]$. This under recognition is likely related to several factors that mainly includes lack of training of medical health care staff to detect distress or emotional issues, in addition to lack of visit time spent with patients [13,20-23], and even lack of resources.

We attempted to describe the pattern of distress in a given urban setting and identify the most common stressors.

\section{Methods}

We enrolled adult cancer patients above the age of 18 receiving chemotherapy for the first time or having their protocol changed. The Distress Thermometer/Problem List (DT/PL) version 3.2012 data was collected from these patients (along with their demographics) in the outpatient infusion center via the nursing staff from 2014 till 2015 (Figure 1) [24].

The sample characteristics were described using mean and standard deviation (SD) for continuous variables and frequencies and percentages for categorical variables. The practical, family, emotional, and physical problem area scores were computed by averaging the single items scores within each problem area resulting in scores ranging from 0 (no reported problems in that area) to 1 (subjects reported having all problems within that area). The mean and median of each problem area score was computed. For the single spiritual problem item, we computed its frequency and percentage. Pearson's correlation coefficient was computed to examine the correlation between the problem areas.
We examined whether the distress thermometer overall scores were different between patients reporting a specific problem item and those not reporting difficulties with that item, using an unpaired t-test.

Using univariate linear regression models, we assessed the association between the distress thermometer score (dependent variable) and each of age, sex, tumor category, and the five problem areas: practical, family, emotional, physical, and spiritual. For this analysis, we first computed the $\mathrm{z}$-scores for the average of each problem area so that the coefficient from the regression analysis corresponds to the change in the distress thermometer score corresponding to a 1-SD change in each of the problem areas' subscale averages.

Multivariate linear regression models were also carried out to examine the association between the distress score (dependent variable) and each of the five problem areas adjusting for age, gender, and tumor category. Unadjusted and adjusted coefficients, 95\% confidence intervals, and the P-values were reported.

Finally, we examined whether the mean of distress score as well as the mean of each problem area varied significantly between the cancer types using one-way Anova tests; a chi-square test was conducted to examine the distribution of the binary (yes/no)-spiritual problem by cancer types. Significance for all tests and regression models was considered at a P-value $<0.05$ and data analysis was done using STATA $_{14}$ software.

\section{Results}

The sample characteristics are presented in Table 1. The majority of the study subjects were females $(61.2 \%)$. The mean of age of the sample was $60(\mathrm{SD}=13.6)$ and the mean of the distress score was $3.6(\mathrm{SD}=3.0)$. The majority of study subjects belonged to the solid tumor category $(81.7 \%)$. One quarter of the patients $(n=60,25.42 \%)$ had breast cancer,

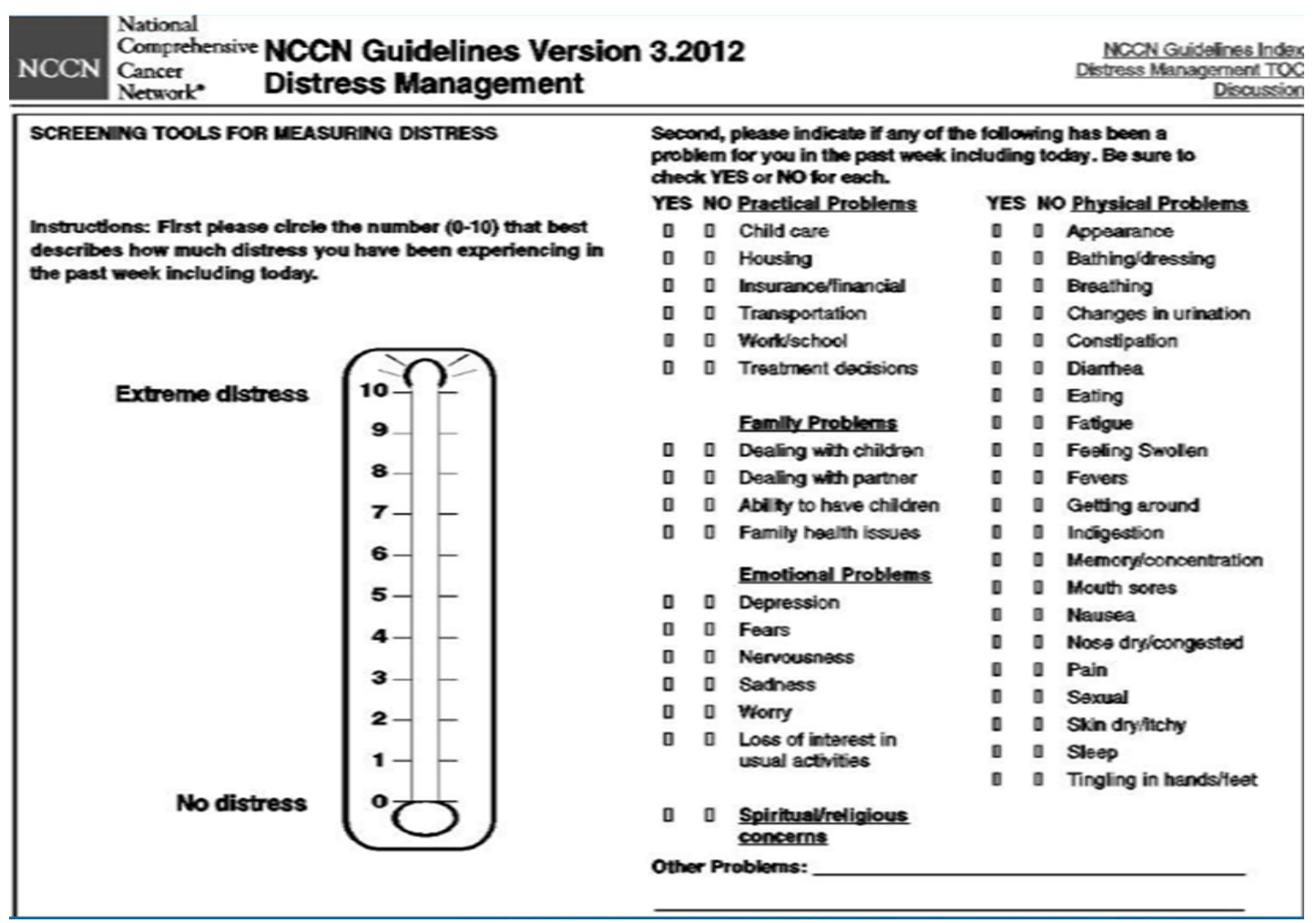

Figure 1. NCCN Distress thermometer/Problem list 
followed by gastro-intestinal $(\mathrm{n}=42,17.8 \%)$ and hematologic cancer types $(\mathrm{n}=40,16.95 \%)$ (Table 1$)$.

The mean score of the family problem area was the lowest $(0.04 \pm$ 0.13 ) while the highest mean score was for the emotional problem area $(0.26 \pm 0.29)$ (Table 2$)$. Concordant results were shown with the median score for each of the four problem areas. The majority of respondents $(\mathrm{n}=197,95.6 \%)$ indicated not having a spiritual problem (Table 2).

The strongest correlation between the problem areas was found between emotional and practical problems (correlation coefficient $=$ 0.38 ), followed by a correlation of 0.30 between practical and family problems (Table 3 ).

Overall, the mean of distress scores ranged between 2.5 and 3.6 among subjects who do not have problems while the mean of distress scores was higher among subjects who have problems, ranging between 3.2 and 7.6 (Table 4). This pattern was observed for all problem areas. The spiritual and all emotional problems were related to higher distress scores (Table 4). Most of the practical and family related problems were associated with higher distress scores. In contrast, only one third of the physical problems were related to higher distress scores (Table 4).

A significant positive association was observed between the distress score and all problem areas except for the spiritual problem (Table 5). The distress score increased on average by 5.48 ( $95 \% \mathrm{CI}=3.03$,

Table 1. Patient characteristics

\begin{tabular}{|l|c|}
\hline Variable & n (\%) or mean (sd) \\
\hline Age & $60.2(13.6)$ \\
\hline Sex & \\
Male & $93(38.8 \%)$ \\
Female & $147(61.2 \%)$ \\
\hline Type of tumor & $196(81.7 \%)$ \\
Solid & $44(18.3 \%)$ \\
\hline Hematologic & $3.6(3.0)$ \\
\hline Distress score & Frequency (\%) \\
\hline Cancer types & $60(25.42 \%)$ \\
\hline Breast cancer & $27(11.44 \%)$ \\
\hline Lung cancer & $42(17.8 \%)$ \\
\hline Gastro-intestinal cancer & $23(9.75 \%)$ \\
\hline Genito-urinary cancer & $22(9.32 \%)$ \\
\hline Gynecologic & $40(16.95 \%)$ \\
\hline Hematologic & $22(9.32 \%)$ \\
\hline Others & $236(100 \%)$ \\
\hline Total & \\
\hline
\end{tabular}

sd: standard deviation; $\mathrm{n}$ : number of patients

Table 2. Mean scores for problem areas

\begin{tabular}{|l|c|c|}
\hline Problem area & Mean score \pm SD & Median \pm IQR \\
\hline Practical problems $(\mathrm{N}=223)$ & $0.09 \pm 0.16$ & $0 \pm 0.17$ \\
\hline Family problems $(\mathrm{N}=220)$ & $0.04 \pm 0.13$ & $0 \pm 0$ \\
\hline Emotional problems $(\mathrm{N}=223)$ & $0.26 \pm 0.29$ & $0.17 \pm 0.4$ \\
\hline Physical problems $(\mathrm{N}=224)$ & $0.16 \pm 0.18$ & $0.10 \pm 0.19$ \\
\hline & \multicolumn{2}{|c|}{ n (\%) } \\
\hline Spiritual problems, yes $(\mathrm{N}=206)$ & \multicolumn{2}{|c|}{$9(4 \%)$} \\
\hline
\end{tabular}

IQR: interquartile range

Table 3. Correlation matrix between the problem areas

\begin{tabular}{|c|c|c|c|c|}
\hline & Mean practical & Mean Family & $\begin{array}{c}\text { Mean } \\
\text { emotional }\end{array}$ & Mean physical \\
\hline Mean practical & 1 & & & \\
\hline Mean Family & 0.3001 & 1 & & \\
\hline Mean emotional & 0.3818 & 0.2478 & 1 & \\
\hline Mean physical & 0.2139 & 0.1825 & 0.2673 & 1 \\
\hline
\end{tabular}

Table 4. Mean distress scores by problem area

\begin{tabular}{|c|c|c|c|c|c|}
\hline $\begin{array}{l}\text { Problem } \\
\text { Area }\end{array}$ & Problem & $\begin{array}{l}\text { Number } \\
\text { reporting } \\
\text { problem }\end{array}$ & \begin{tabular}{c|} 
No \\
Mean (SD)
\end{tabular} & $\begin{array}{c}\text { Yes } \\
\text { Mean (SD) }\end{array}$ & P-value \\
\hline \multirow{6}{*}{ Practical } & Child care & 3 & $3.5(3.0)$ & $6.0(2.0)$ & 0.16 \\
\hline & Housing & 8 & $3.4(3.0)$ & $6.1(2.6)$ & $0.012 *$ \\
\hline & Insurance & 41 & $3.2(2.9)$ & $5.0(3.0)$ & $0.0004 * *$ \\
\hline & Transportation & 23 & $3.4(2.9)$ & $5.2(3.4)$ & $0.006^{* *}$ \\
\hline & Work/school & 21 & $3.5(3.1)$ & $4.0(2.6)$ & 0.477 \\
\hline & Treatment decisions & 20 & $3.3(2.9)$ & $5.5(2.9)$ & $0.002 * *$ \\
\hline \multirow{4}{*}{ Family } & Dealing with children & 8 & $3.4(3.0)$ & $6.8(2.0)$ & $0.002 * *$ \\
\hline & Dealing with spouse & 5 & $3.5(3.0)$ & $7.6(1.1)$ & $0.002 * *$ \\
\hline & Ability to have children & 5 & $3.5(3.0)$ & $4.6(3.0)$ & 0.429 \\
\hline & Family health issues & 16 & $3.3(2.9)$ & $6.3(2.7)$ & $0.0001 * *$ \\
\hline \multirow{6}{*}{ Emotional } & Depression & 26 & $3.1(2.9)$ & $6.3(2.7)$ & $0.000 * *$ \\
\hline & Fears & 57 & $2.8(2.8)$ & $5.5(2.7)$ & $0.000 * *$ \\
\hline & Nervousness & 79 & $3.0(3.0)$ & $4.5(2.8)$ & $0.0006^{* *}$ \\
\hline & Sadness & 51 & $2.9(2.8)$ & $5.5(2.8)$ & $0.000^{* *}$ \\
\hline & Worry & 85 & $2.5(2.7)$ & $5.0(2.9)$ & $0.000 * *$ \\
\hline & $\begin{array}{l}\text { Loss of interest in usual } \\
\text { activities }\end{array}$ & 28 & $3.1(2.9)$ & $6.3(2.5)$ & $0.000^{* *}$ \\
\hline Spiritual & Religious concerns & 9 & $3.5(3.0)$ & $5.6(3.1)$ & 0.051 \\
\hline \multirow{21}{*}{ Physical } & Appearance & 14 & $3.4(2.9)$ & $5.3(3.1)$ & $0.026^{*}$ \\
\hline & Bathing/dressing & 12 & $3.4(3.0)$ & $6.3(2.5)$ & $0.0013 * *$ \\
\hline & Breathing & 16 & $3.5(3.0)$ & $4.6(3.5)$ & 0.14 \\
\hline & Changes in urination & 13 & $3.5(3.0)$ & $5.0(2.7)$ & $0.09 *$ \\
\hline & Constipation & 35 & $3.4(2.9)$ & $4.2(3.4)$ & 0.12 \\
\hline & Diarrhea & 9 & $3.6(3.0)$ & $4.2(3.1)$ & 0.55 \\
\hline & Eating & 44 & $3.3(2.8)$ & $4.6(3.3)$ & $0.008 * *$ \\
\hline & Fatigue & 70 & $3.4(3.0)$ & $3.8(3.1)$ & 0.447 \\
\hline & Feeling swollen & 26 & $3.6(3.0)$ & $3.5(2.9)$ & 0.97 \\
\hline & Fevers & 6 & $3.5(3.0)$ & $4.0(3.7)$ & 0.693 \\
\hline & Getting around & 28 & $3.4(2.9)$ & $4.9(3.1)$ & $0.01 *$ \\
\hline & Indigestion & 21 & $3.5(3.0)$ & $4.4(3.2)$ & 0.189 \\
\hline & Memory/concentration & 33 & $3.5(3.0)$ & $3.7(3.3)$ & 0.776 \\
\hline & Mouth sores & 13 & $3.5(3.0)$ & $4.0(2.9)$ & 0.586 \\
\hline & Nausea & 25 & $3.4(3.0)$ & $4.4(3.2)$ & 0.125 \\
\hline & Nose dry/congested & 28 & $3.6(3.0)$ & $3.2(2.9)$ & 0.555 \\
\hline & Pain & 57 & $3.0(2.9)$ & $4.8(3.0)$ & $0.0003 * *$ \\
\hline & Sexual & 13 & $3.6(3.0)$ & $4.1(3.6)$ & 0.552 \\
\hline & Skin dry/itchy & 49 & $3.5(3.0)$ & $3.6(3.1)$ & 0.916 \\
\hline & Sleep & 66 & $3.1(2.8)$ & $4.5(3.2)$ & $0.002 * *$ \\
\hline & Tingling in hands/feet & 35 & $3.5(3.1)$ & $4.1(2.7)$ & 0.275 \\
\hline
\end{tabular}

** P-value $<0.01 ; *$ P-value $<0.05$.

7.92) points comparing subjects with no practical problems to those reporting having all the six practical problems (Table 5). Similarly, the distress scores increased by 7.55 (95\% CI=4.46, 10.64) points for people having all family problems compared to those with none and it increased by $5.41(95 \% \mathrm{CI}=4.18,6.63)$ for people reporting all emotional problems in comparison to people reporting none (Table 5). Likewise, the distress score increased on average by 4.11 (95\% CI $=1.63$, 6.58) points comparing subjects reporting no physical problems to those reporting all the 21 physical problems (Table 5). In contrast, a significant negative association was observed between distress score and sex, with a $0.87(95 \% \mathrm{CI}=-1.71,-0.02)$ lower score for men. No significant association was observed between distress score and age and between distress score and tumor category (Table 5). Results were concordant when the models of the five problem areas were adjusted for age, sex, and tumor category (Table 6).

The highest mean of distress score $(4.91, \mathrm{SD}=3.57)$ was observed in patients with lung cancer while the lowest mean of distress score $(2.56$, 
$\mathrm{SD}=2.37$ ) was observed in patients with genito-urinary cancer (Table $7)$. However, the difference in the mean of distress scores between the cancer types was not significant $(\mathrm{P}$-value $=0.107)($ Table 7$)$. Of all the five problem areas, the mean of the physical problem area was the only one to show significant difference between the cancer types $(\mathrm{P}$-value $=0.003)($ Tables 8 and 9$)$. Lung $($ mean $=0.23, \mathrm{SD}=0.20)$ and genito-urinary (mean $=0.23, \mathrm{SD}=0.26$ ) cancer patients had the highest physical problems whereas hematology cancer patients had the lowest physical problems (mean $=0.10 ; \mathrm{SD}=0.10)$ (Table 8 and 9).

\section{Discussion}

In this sample representing a single institution in Washington DC, $35 \%$ of our patients were found to have significant level of distress $(\mathrm{DT} \geq 5)$. Our results go along with other reports like Kendell, et al. (33\%) but different than others like those reported by Meggiolaro, et al. (60\%) and Mehnert, et al. (52\%) [15,25,26]. This difference is expected as different patient samples in their varying demographics, cancer types, and treatments will more likely yield different distress measurements. As for the mean distress in our sample (3.6), it is

Table 5. Results of univariate linear regression models for the distress score

\begin{tabular}{|l|c|c|c|}
\hline Predictor & $\begin{array}{c}\text { Unadjusted } \\
\text { coefficients }\end{array}$ & $\mathbf{9 5 \%}$ CI & p-value \\
\hline Age (N=207) & -0.004 & {$[-0.03,0.03]$} & 0.816 \\
\hline Sex (Male) (N=207) & -0.87 & {$[-1.71,-0.02]$} & $0.045^{*}$ \\
\hline $\begin{array}{l}\text { Category (solid) } \\
(207)\end{array}$ & 0.96 & {$[-0.12,2.03]$} & 0.080 \\
\hline $\begin{array}{l}\text { Practical problems } \\
(\mathrm{N}=201)\end{array}$ & 0.88 & {$[0.49,1.27]$} & $0.000^{* *}$ \\
\hline $\begin{array}{l}\text { Family problems } \\
(\mathrm{N}=200)\end{array}$ & 0.98 & {$[0.58,1.38]$} & $0.000^{* *}$ \\
\hline $\begin{array}{l}\text { Emotional problems } \\
(\mathrm{N}=201)\end{array}$ & 1.03 & {$[0.79,1.26]$} & $0.000^{* *}$ \\
\hline $\begin{array}{l}\text { Physical problems } \\
(\mathrm{N}=194)\end{array}$ & 0.74 & {$[-0.01,4.04]$} & $0.001^{* *}$ \\
\hline $\begin{array}{l}\text { Spiritual problem } \\
\text { (yes) (N=186) }\end{array}$ & 2.01 & 0.051 \\
\hline
\end{tabular}

$* *$ P-value $<0.01, *$ P-value $<0.05$.

CI: confidence interval

Table 6. Results of multivariate linear regression models for the distress outcome and each of the problem areas adjusted for age, sex, and category type

\begin{tabular}{|l|c|c|c|}
\hline Predictor & $\begin{array}{c}\text { Adjusted } \\
\text { coefficients }\end{array}$ & $\mathbf{9 5 \%}$ CI & p-value \\
\hline Practical problems (N=201) & 0.87 & {$[0.46,1.27]$} & $0.000^{* *}$ \\
\hline Family problems $(\mathrm{N}=200)$ & 0.96 & {$[0.55,1.37]$} & $0.000^{* *}$ \\
\hline Emotional problems (N=201) & 1.00 & {$[0.77,1.24]$} & $0.000^{* *}$ \\
\hline Physical problems (N=194) & 0.74 & {$[0.28,1.19]$} & $0.002^{* *}$ \\
\hline Spiritual problem (Yes) $(\mathrm{N}=186)$ & 1.70 & {$[-0.36,3.75]$} & 0.105 \\
\hline
\end{tabular}

$* *$ P-value $<0.01, *$ P-value $<0.05$

$\mathrm{CI}$ : confidence interval

Table 7. Mean of distress score by the cancer types $(\mathrm{N}=203)$

\begin{tabular}{|c|c|c|c|c|}
\hline Cancer category & Mean & $\begin{array}{l}\text { Standard } \\
\text { deviation }\end{array}$ & $\mathbf{n}$ & P-value \\
\hline Breast cancer & 3.51 & 2.85 & 57 & \multirow{8}{*}{0.107} \\
\hline Lung cancer & 4.91 & 3.57 & 22 & \\
\hline Gastro-intestinal cancer & 3.46 & 3.11 & 35 & \\
\hline Genito-urinary cancer & 2.56 & 2.37 & 16 & \\
\hline Gynecology cancer & 4.71 & 2.76 & 21 & \\
\hline Hematology cancer & 3.03 & 3.02 & 32 & \\
\hline Others & 3.50 & 2.70 & 20 & \\
\hline Total & 3.63 & 2.99 & 203 & \\
\hline
\end{tabular}

** P-value $<0.01 ; *$ P-value $<0.05$.
Table 8. Mean of the practical, family, emotional, and physical problem areas by the cancer types

\begin{tabular}{|c|c|c|c|c|}
\hline & Mean & $\begin{array}{l}\text { Standard } \\
\text { deviation }\end{array}$ & $\mathbf{n}$ & P-value \\
\hline \multicolumn{5}{|c|}{ Practical problem area $(\mathrm{N}=219)$} \\
\hline Breast cancer & 0.12 & 0.19 & 58 & \multirow{7}{*}{0.274} \\
\hline Lung cancer & 0.08 & 0.13 & 26 & \\
\hline Gastro-intestinal & 0.09 & 0.17 & 37 & \\
\hline Genito-urinary & 0.04 & 0.07 & 20 & \\
\hline Gynecology & 0.14 & 0.20 & 21 & \\
\hline Hematology & 0.06 & 0.11 & 37 & \\
\hline Others & 0.09 & 0.14 & 20 & \\
\hline \multicolumn{5}{|c|}{ Family problem area $(\mathrm{N}=216)$} \\
\hline Breast cancer & 0.07 & 0.15 & 58 & \multirow{7}{*}{0.28} \\
\hline Lung cancer & 0.03 & 0.11 & 24 & \\
\hline Gastro-intestinal & 0.06 & 0.14 & 36 & \\
\hline Genito-urinary & 0.00 & 0.00 & 20 & \\
\hline Gynecology & 0.06 & 0.18 & 21 & \\
\hline Hematology & 0.03 & 0.10 & 37 & \\
\hline Others & 0.01 & 0.06 & 20 & \\
\hline \multicolumn{5}{|c|}{ Physical problem area $(\mathrm{N}=220)$} \\
\hline Breast cancer & 0.11 & 0.12 & 56 & \multirow{7}{*}{$0.003 * *$} \\
\hline Lung cancer & 0.23 & 0.20 & 26 & \\
\hline Gastro-intestinal & 0.19 & 0.19 & 38 & \\
\hline Genito-urinary & 0.23 & 0.26 & 22 & \\
\hline Gynecology & 0.21 & 0.22 & 19 & \\
\hline Hematology & 0.10 & 0.10 & 39 & \\
\hline Others & 0.18 & 0.17 & 20 & \\
\hline \multicolumn{5}{|c|}{ Emotional problem area $(\mathrm{N}=219)$} \\
\hline Breast cancer & 0.32 & 0.31 & 58 & \multirow{7}{*}{0.238} \\
\hline Lung cancer & 0.35 & 0.32 & 25 & \\
\hline Gastro-intestinal & 0.26 & 0.32 & 37 & \\
\hline Genito-urinary & 0.20 & 0.28 & 21 & \\
\hline Gynecology & 0.25 & 0.26 & 21 & \\
\hline Hematology & 0.19 & 0.20 & 37 & \\
\hline Others & 0.25 & 0.26 & 20 & \\
\hline
\end{tabular}

** P-value $<0.01 ; *$ P-value $<0.05$.

Table 9. Distribution of the spiritual problem (yes/No) by the cancer categories $(\mathrm{N}=202)$

\begin{tabular}{|l|c|c|c|c|}
\hline \multirow{2}{*}{$\begin{array}{l}\text { Cancer } \\
\text { categories }\end{array}$} & \multicolumn{2}{|c|}{ Spiritual (No) } & \multicolumn{2}{c|}{ Spiritual (Yes) } \\
\cline { 2 - 5 } & $\mathrm{n}$ & $\%$ & $\mathrm{n}$ & $\%$ \\
\hline Breast cancer & 46 & $23.83 \%$ & 3 & $33.33 \%$ \\
\hline Lung cancer & 24 & $12.44 \%$ & 1 & $11.11 \%$ \\
\hline Gastro-intestinal & 31 & $16.06 \%$ & 2 & $22.22 \%$ \\
\hline Genito-urinary & 18 & $9.33 \%$ & 0 & $0 \%$ \\
\hline Gynecology & 19 & $9.84 \%$ & 2 & $22.22 \%$ \\
\hline Hematology & 35 & $18.13 \%$ & 1 & $11.11 \%$ \\
\hline Others & 20 & $10.36 \%$ & 0 & $0 \%$ \\
\hline Total & 193 & $100 \%$ & 9 & $100 \%$ \\
\hline P-value & & \multicolumn{2}{|c|}{0.702} & \\
\hline
\end{tabular}

** P-value $<0.01 ; *$ P-value $<0.05$.

lower than that described by Mehnert, et al. (4.55), but similar to that reported by Jacobson, et al. (3.41) [27]. Again signifying the fact that different population of patients report different levels of distress, and thus understanding each population might entail different approaches to managing their distress.

The highest mean distress score was observed in lung cancer patients while the lowest in genitourinary cancer patients (Table 7). Given the small number of patients in the study, no significant difference was found between distress scores among various cancer subtypes. Distress in various cancer subtypes is another area where 
variation among studies is observed. Mehnert, et al. reported highest levels of distress in females with genital cancers, while Admiraal, et al. report lowest distress in prostate cancer patients [28].

The highest number of patients reporting problems in the problem list was in the emotional problem area (Table 4). Patients reporting a problem in this area almost have double the score on the distress thermometer. Although there was a pattern of increased distress scores among patients who reported problems in various problem areas, there was variability in the physical problem area whereby only around onethird of the physical problems reported were associated with higher distress scores. The physical problem areas associated with increased distress were those related to patient autonomy like bathing/dressing, eating, getting around, sleep and pain.

We also found in our study that practical problems are strongly correlated with emotional problems followed by family problems (Table 3). This is important as, in this population of patients, those who report practical problems involving childcare, housing, insurance, transportation, work/school, need to be further screened for depression, fear, anxiety/nervousness and worry.

\section{Conclusion}

Our results provide health care providers in the Washington DC area with insights into the various physical and psychosocial distresses that cancer patients in this area face. This study should encourage these health care professionals to screen their cancer patients for distress and subsequently refer them to specific subspecialties for further management. The variation in our numbers when compared to those reported in different population of patients should also provide incentive to various health care professionals to study their own population of patients and subsequently provide them with the best personalized care possible. Future directions include medical and counseling interventions in our patients with significant distress and assessing these interventions" effects on quality of life and overall survival.

\section{References}

1. Riba MB, Donovan KA, Andersen B, Braun I, Breitbart WS, et al. (2019) Distress Management, Version 3.2019, NCCN Clinical Practice Guidelines in Oncology. J Natl Compr Canc Netw 17: 1229-49. [Crossref]

2. APOS (2000) APOS Standards of Care for the Management of Distress in Patients with Cancer. American Psychosocial Oncology Society Charlottesville, VA.

3. Silver SM (2008) Cancer care for the whole patient-a new institute of medicine report. J Oncol Pract 4: 131. [Crossref]

4. Facktor MA (2018) The Role of Quality Metrics in Improving Oncologic Survival. Quality Cancer Care pp: 85-94.

5. Cleeland CS, Bennett GJ, Dantzer R, Dougherty PM, Dunn AJ, et al. (2003) Are the symptoms of cancer and cancer treatment due to a shared biologic mechanism? A cytokine-immunologic model of cancer symptoms. Cancer 97: 2919-2925. [Crossref]

6. Dantzer R, O'Connor JC, Freund GG, Johnson RW, Kelley KW (2008) From inflammation to sickness and depression: when the immune system subjugates the brain. Nat Rev Neurosci 9: 46-56. [Crossref

7. Reiche EM, Nunes SO, Morimoto HK (2004) Stress, depression, the immune system, and cancer. Lancet Oncol 5: 617-625. [Crossref]
8. 8. Berry DL, Blonquist TM, Hong F, Halpenny B, Partridge AH. Self-reported adherence to oral cancer therapy: relationships with symptom distress, depression, and personal characteristics. Patient Prefer Adherence 9: 1587-1592. [Crossref]

9. DiMatteo MR, Lepper HS, Croghan TW (2000) Depression is a risk factor for noncompliance with medical treatment: meta-analysis of the effects of anxiety and depression on patient adherence. Arch Intern Med 160: 2101-2107. [Crossref]

10. Brown KW, Levy AR, Rosberger Z, Edgar L (2003) Psychological distress and cancer survival: a follow-up 10 years after diagnosis. Psychosom Med 65: 636-643. [Crossref]

11. Massie MJ (2004) Prevalence of depression in patients with cancer. J Natl Cancer Inst Monogr pp: 57-71.

12. Pirl WF, Greer JA, Traeger L, Jackson V, Lennes IT, et al. (2012) Depression and survival in metastatic non-small-cell lung cancer: effects of early palliative care. $J$ Clin Oncol 30: 1310-1315. [Crossref]

13. Fallowfield L, Ratcliffe D, Jenkins V, Saul J (2001) Psychiatric morbidity and its recognition by doctors in patients with cancer. Br J Cancer 84: 1011-1015. [Crossref]

14. Hegel MT, Moore CP, Collins ED, Kearing S, Gillock KL, et al. (2006) Distress, psychiatric syndromes, and impairment of function in women with newly diagnosed breast cancer. Cancer 107: 2924-2931. [Crossref]

15. Mehnert A, Hartung TJ, Friedrich M, Vehling S, Brahler E, et al. (2018) One in two cancer patients is significantly distressed: Prevalence and indicators of distress. Psychooncology 27: 75-82. [Crossref]

16. Zabora J, BrintzenhofeSzoc K, Curbow B, Hooker C, Piantadosi S (2001) The prevalence of psychological distress by cancer site. Psychooncology 10: 19-28. [Crossref]

17. Mitchell AJ, Vahabzadeh A, Magruder K (2011) Screening for distress and depression in cancer settings: 10 lessons from 40 years of primary-care research. Psychooncology 20: 572-584. [Crossref]

18. Mitchell AJ, Hussain N, Grainger L, Symonds P. Identification of patient-reported distress by clinical nurse specialists in routine oncology practice: a multicentre UK study. Psychooncology 20: 1076-1083. [Crossref]

19. Werner A, Stenner C, Schuz J (2012) Patient versus clinician symptom reporting: how accurate is the detection of distress in the oncologic after-care? Psychooncology 21 818-826. [Crossref]

20. Greer S. Healing the mind/body split: bringing the patient back into oncology. Integr Cancer Ther 2: 5-12. [Crossref]

21. Plummer SE, Gournay K, Goldberg D, Ritter SA, Mann AH, et al. (2000) Detection of psychological distress by practice nurses in general practice. Psychol Med 30: 12331237. [Crossref]

22. Ryan H, Schofield P, Cockburn J, Butow P, Tattersall M, et al. (2005) How to recognize and manage psychological distress in cancer patients. Eur J Cancer Care (Engl) 14: 7-15. [Crossref]

23. Stewart MA (1995) Effective physician-patient communication and health outcomes: a review. CMAJ 152: 1423-33. [Crossref]

24. Holland JC, Andersen B, Breitbart WS, Buchmann LO, Compas B, et al. (2013) Distress management. J Natl Compr Canc Netw 11: 190-209. [Crossref]

25. Kendall J, Glaze K, Oakland S, Hansen J, Parry C. What do 1281 distress screeners tell us about cancer patients in a community cancer center? Psychooncology. 2011;20(6):594-600. [Crossref]

26. Meggiolaro E, Berardi MA, Andritsch E, Nanni MG, Sirgo A, et al. (2016) Cance patients' emotional distress, coping styles and perception of doctor-patient interaction in European cancer settings. Palliat Support Care 14: 204-11. [Crossref]

27. Jacobsen PB, Ransom S (2007) Implementation of NCCN distress management guidelines by member institutions. $J$ Natl Compr Canc Netw 5: 99-103. [Crossref]

28. Admiraal J, Reyners A, Hoekstra-Weebers J (2013) Do cancer and treatment type affect distress? Psycho-Oncology 22: 1766-1773. [Crossref]

Copyright: (C2020 Yamout R. This is an open-access article distributed under the terms of the Creative Commons Attribution License, which permits unrestricted use, distribution, and reproduction in any medium, provided the original author and source are credited. 